\title{
Biodiversity of Halophytic Vegetation in Chott Zehrez Lake of Djelfa (Algeria)
}

\author{
Bouzid Nedjimi $^{* *}$, Brahim Beladel ${ }^{2}$, Brahim Guit ${ }^{1}$ \\ ${ }^{1}$ Laboratoire d'Exploration et Valorisation des Ecosystèmes Steppiques, Faculté des Sciences de la Nature et de la Vie, Université de \\ Djelfa, Djelfa, Algeria; ${ }^{2}$ Faculté des Sciences de la Nature et de la Vie, Université de Djelfa, Djelfa, Algeria. \\ Email: "bnedjimi@yahoo.fr
}

Received August 10 ${ }^{\text {th }}, 2012$; revised September 17 $7^{\text {th }}, 2012$; accepted October $15^{\text {th }}, 2012$

\begin{abstract}
Mediterranean large lakes play an important role in providing a range of ecosystem functions and supporting biodiversity. The conservation and management of these lakes require more detailed knowledge of their ecology and environment-vegetation relationships. Chotts are probably the most poorly understood lake ecosystems. Chott Zehrez (Djelfa) as a large, shallow lake ecosystem in Algerian steppes, where wetlands are important part of their productivity. Despite the status of chott Zehrez lake as a Ramsar site, the main threat to its conservation is the private nature of surrounding land holdings in addition to the lack of knowledge and awareness by the local population of the importance of lake ecosystems. A wealth of halophytic flora exists which can be exploited for an array of uses like fodder, fuel wood, oilseed, medicines, landscaping, and environment conservation through carbon sequestration. A total 112 species belonging to 26 families and 39 genera were recorded. The sabkha flora includes 9 endangered and endemic species such as Avena bromoides, Cutandia divaricata, Herniaria mauritanica and Salicornia arabica. In this paper we mainly discussed characteristics and importance of Chott Zehrez lake ecosystem, its vegetation potentialities and economic usages will be also presented and discussed. Finally conservation strategy and restoration of this ecosystem are suggested.
\end{abstract}

Keywords: Algeria; Chott Zehrez; Endemic Species; Economic Potential; Halophytes; Sebkha

\section{Introduction}

Lakes in Algeria have, for a long time, been a source of water for humans and their livestock, especially during dry seasons. They also support a rich biodiversity and are of major importance for migratory birds and constitute wintering grounds for thousands of ducks, coots, geese, and flamingos. Currently 42 out of the 300 lakes in Algeria are listed under the Ramsar Convention covering an area of 3 million ha [1].

The most characteristic types of lake in Algeria are endorheic lakes. They consist of chotts and sebkhas, as known in Arabic, also referred to as Athalassic salt lakes. The term athalassic denotes saline waters which are isolated from the sea, or which were once connected to the sea, but which have dried out before being re-flooded by water of non-marine origin [1]. The chotts and sebkhas are typically seasonal lake which dry out in summer and re-flood in winter. According to [2], sebkha is the central zone of saline lake dominated by water and devoid of vegetation due to high salt concentrations. The chott is the surrounding zone which forms a vegetation ring around the water. This vegetation is mainly composed of

*Corresponding author. halophytic, succulent and perennial species. In these environments the main factors controlling vegetation are water salinity in the growing season and the depth and period of flooding. Vegetation at the edges of the Chotts comprises mainly members of the Chenopodiaceae family (such as Atriplex ssp., Salsola ssp., Suaeda ssp. and Salicornia ssp.) Among the most important chotts in Algeria is Chott Zehrez, the second largest Chott in North Africa [1]. However, as far as we know, there has not been a lot of research conducted on these systems.

Several efforts were made to compile a list of the halophytic flora of the world [3] as well as a list of regional halophytes. However, the information regarding halophytes is still far from complete. The flora of Algeria is near completion and also has information about the halophytes. Currently, effort is being made to compile a list of halophytes in Algeria, with their distribution, ecology and potential economic usages.

Halophytes and other salt-tolerant plants may provide sensible alternatives for many developing countries [4]. These plants can grow in saline to extremely saline habitats and have particular characteristics which enable them to evade and/or tolerate salinity by various eco-physio- 
logical mechanisms. These plants are naturally grown in salt affected lands such as in salt lakes, marshes, sloughs, saline soils and seashores. The vegetative yields of halophytes and other salt-tolerant plants species could have great economic potentialities in the arid and semi-arid areas [5]. There are many halophytes and salt-tolerant shrubs and grasses which could be established in saline lands (e.g. Kochia sp., Juncus sp., Acacia sp., Suaeda sp., Salsola sp. and Atriplex sp.). Although economic consideration of halophytes and other salt-tolerant plants is just beginning, they are now receiving increased attention particularly in arid regions where salinity problems are very crucial.

Despite their international importance in Algeria, Chott Lakes have attracted little attention concerning their floristic composition and ecological processes. The objectives of this study are to focus on 1) the understanding the Chott Zehrez as a large, shallow lake ecosystem where wetlands are important and its ecological threats 2) to identify the different plant communities present in the area of Chott Zehrez lake and 3) to describe the economic potential use of a wide range of halophytes and other salt tolerant vegetation.

\section{Site Description}

The study was undertaken in a salt Chott of Zehrez Djelfa, which is located to the north of Algeria $\left(3^{\circ} 03^{\prime} \mathrm{E}\right.$ longitude, $34^{\circ} 36^{\prime} \mathrm{N}$ latitude) (Figure 1). The Chott area is about 50.985 ha and the altitude ranges from $840 \mathrm{~m}$ to $825 \mathrm{~m}$. The geology consists mainly of cretaceous, with deposits of quaternary. According to [2] principal type of soils in Chott Zehrez wetland are the calci-magnesic solontchak and hydromorphic soils (gley). The Sebkha soils are characterised by saline silts, prone to flooding in winter and covered by salty crusts in summer [6]. The endorheic nature of the area and the flat relief induce water accumulation in the Chott from winter rainfall. The saline soils (solontchaks) are poorly developed and contain a high amount of exchangeable sodium and soluble salts. The texture changes from silt-clays to silt-sands [7]. Soil salinity ranges from 1.99 to $4.47 \mathrm{dS} \cdot \mathrm{m}^{-1}$. The water table varies from 1 to $3 \mathrm{~m}$ below the surface (Figure 2). The climate of Chott Zehrez is typically Mediterranean, characterised by wet winters and hot dry summers with a mean annual precipitation of $250 \mathrm{~mm} \cdot$ year $^{-1}$ (2000-2010). The average minimum winter and maximum summer temperatures are $5^{\circ} \mathrm{C}$ in January and $26^{\circ} \mathrm{C}$ in July, respectively. The rainy season is generally from mid-October to May [8].

The natural vegetation is represented by halophytes such as Atriplex halimus, Suaeda fruticosa, Salsola vermiculata and Salicornia fruticosa. A number of rare and

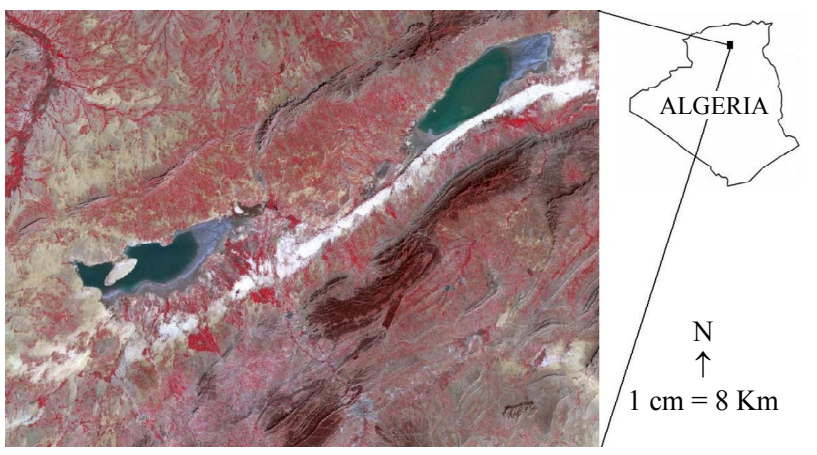

Figure 1. Location of the study area (Image LANDSAT 2001).

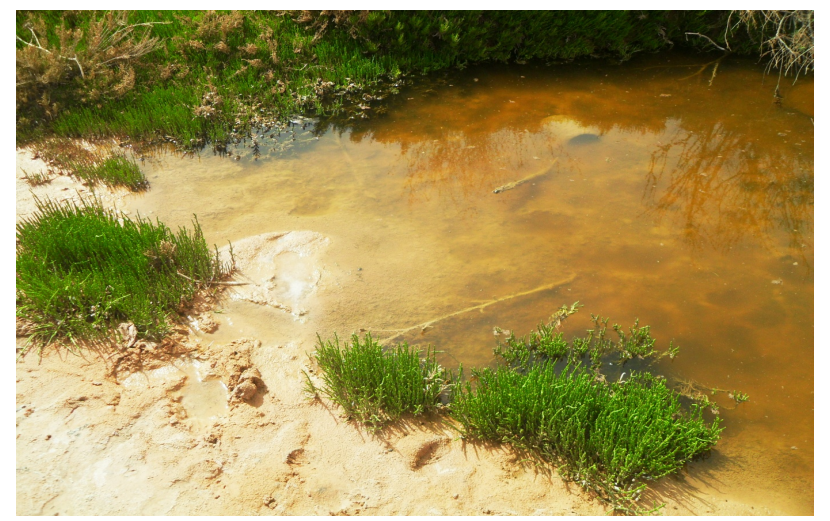

Figure 2. Salicornia sp. is often the dominant species on Chott Zehrez Lake, The pools of water in the foreground indicate the high level of the groundwater (Photo Senni R., 2010).

endemic plant species are found, including: Herniaria mauritanica, Salicornia arabica, Avena bomoides, Hordeum maritimu, Juncus bufonius, Launaea resedfolia, Polygonum equisetforme and Reaumuria venniculata [9].

The Chott Zehrez lake is very important for breeding and over-wintering of many bird populations. There is a diversity of species many of which are rare and threatened. These include Outarde (Chlamydotis undulata), different types of ducks: Anas penelope, Anas clypeata, Anas platyrhynchos and other birds such as Falco tinnunculus; Columba livia and Tyto alba. This relatively diverse flora and fauna was a critical factor in the designation of the Chott as a RAMSAR site.

\section{Halophytic Vegetation Description}

The region of Chott Zehrez lake investigated in this study is characteristic of the salt marshes (Sebkha and Chott) situated in the northern part of Algeria (Djelfa). The results demonstrated that halophytic and hydrohalophytic communities constitute the natural vegetation of the area. 112 species belonging to 26 families and 39 genera were recorded (Table 1). Nine of the recorded species were endemic representing $8 \%$ of the total species. The richest 
Table 1. Alphabetical listing of vegetation in Chott Zehrez lake of Algeria (Those with an asterisk $\left(^{*}\right)$ are endemic in Algeria, with two asterisks $\left({ }^{* *}\right)$ are rare species).

\begin{tabular}{|c|c|c|c|c|}
\hline $\mathbf{N}^{\mathrm{br}}$ & Species & Family & Plant type $^{1}$ & Life form ${ }^{2}$ \\
\hline 01 & Aeluropus littoralis & Poaceae & Hydrohalophyte & Chamaephyte \\
\hline 02 & Agropyron orientale & Poaceae & Xerophyte & Therophyte \\
\hline 03 & Aizoon hispanicum & Aizoaceae & Xerohalophyte & Therophyte \\
\hline 04 & Ammochloa palaestina & Poaceae & Psammophyte & Therophyte \\
\hline 05 & Anacyclus clavatus & Asteraceae & Weedy & Therophyte \\
\hline 06 & Anacyclus cyrtolepidioides* & Asteraceae & Xerophyte & Therophyte \\
\hline 07 & Artemisia campestris & Asteraceae & Psammophyte & Phanerophyte \\
\hline 08 & Artemisia herba-alba & Asteraceae & Psammophyte & Phanerophyte \\
\hline 09 & Arthrocnemum indicum & Chenopodiaceae & Hydrohalophyte & Phanerophyte \\
\hline 10 & Arthrophytum schmittianum & Chenopodiaceae & Halophyte & Phanerophyte \\
\hline 11 & Arthrophytum scoparium & Chenopodiaceae & Halophyte & Phanerophyte \\
\hline 12 & Astragalus cruciatus & Fabaceae & Xerohalophyte & Chamaephyte \\
\hline 13 & Astragalus tenuifoliosus & Fabaceae & Xerohalophyte & Chamaephyte \\
\hline 14 & Atractylis carduus & Asteraceae & Psammophyte & Chamaephyte \\
\hline 15 & Atriplex glauca & Chenopodiaceae & Xerohalophyte & Phanerophyte \\
\hline 16 & Atriplex halimus & Chenopodiaceae & XeroHalophyte & Phanerophyte \\
\hline 17 & Atriplex portulacoides & Chenopodiaceae & XeroHalophyte & Phanerophyte \\
\hline 18 & Avena bromoides ${ }^{* *}$ & Poaceae & Weedy & Hemicryptophyte \\
\hline 19 & Bassia muricata & Chenopodiaceae & Xerohalophyte & Therophyte \\
\hline 20 & Beta macrocarpa & Chenopodiaceae & Xerohalophyte & Phanerophyte \\
\hline 21 & Biscutella auriculata & Brassicaceae & Xerophyte & Therophyte \\
\hline 22 & Bupleurum semicompositum & Apiaceae & Weedy & Therophyte \\
\hline 23 & Centaurium pulchellum & Gentianaceae & Psammophyte & Chamaephyte \\
\hline 24 & Cordylocarpus muricatus ${ }^{*}$ & Brassicaceae & Weedy & Therophyte \\
\hline 25 & Coronopus squamatus & Brassicaceae & Xerohalophyte & Therophyte \\
\hline 26 & Cressa cretica & Convolvulaceae & Hydrohalophyte & Chamaephyte \\
\hline 27 & Ctenopis pectinella & Poaceae & Psammophyte & Therophyte \\
\hline 28 & Cutandia dichotoma & Poaceae & Psammophyte & Therophyte \\
\hline 29 & Cutandia divaricata* $^{* *}$ & Poaceae & Psammophyte & Therophyte \\
\hline 30 & Cynodon dactylon & Poaceae & Weedy & Chamaephyte \\
\hline 31 & Diplotaxis harra & Brassicaceae & Psammophyte & Therophyte \\
\hline 32 & Enarthrocarpus clavatus ${ }^{*}$ & Brassicaceae & Xerophyte & Therophyte \\
\hline 33 & Erodium glaucophyllum & Geraniaceae & Xerophyte & Therophyte \\
\hline 34 & Euphorbia falcata & Euphorbiaceae & Weedy & Therophyte \\
\hline 35 & Frankenia pulverulenta & Frankeniaceae & Psammophyte & Therophyte \\
\hline 36 & Frankenia thymifolia* & Frankeniaceae & Psammophyte & Therophyte \\
\hline 37 & Halocnemum strobilaceum & Chenopodiaceae & Xerohalophyte & Phanerophyte \\
\hline
\end{tabular}




\section{Continued}

\begin{tabular}{|c|c|c|c|c|}
\hline 38 & Halogeton sativus & Chenopodiaceae & Xerohalophyte & Phanerophyte \\
\hline 39 & Halopeplis amplexicaulis & Chenopodiaceae & Xerohalophyte & Phanerophyte \\
\hline 40 & Hedypnois cretica & Asteraceae & Weedy & Therophyte \\
\hline 41 & Helianthemum hirtum ${ }^{*}$ & Cistaceae & Psammophyte & Chamaephyte \\
\hline 42 & Helianthemum kahiricum & Cistaceae & Psammophyte & Chamaephyte \\
\hline 43 & Helianthemum lippii & Cistaceae & Psammophyte & Chamaephyte \\
\hline 44 & Herniaria fontanesii & Paronychioideae & Xeropgypsophyte & Chamaephyte \\
\hline 45 & Herniaria hirsuta & Paronychioideae & Xeropgypsophyte & Hemicryptophyte \\
\hline 46 & Herniaria mauritanica ${ }^{*}$ & Paronychioideae & Xeropgypsophyte & Chamaephyte \\
\hline 47 & Hordeum maritimum $^{* *}$ & Poaceae & Hydrohalophyte & Chamaephyte \\
\hline 48 & Hutchinsia procumens & Brassicaceae & Xerohalophyte & Therophyte \\
\hline 49 & Inula crithmoides & Asteraceae & Hydrohalophyte & Chamaephyte \\
\hline 50 & Imperata cylindrica & Poaceae & Psammophyte & Phanerophyte \\
\hline 51 & Juncus bufonius $^{* *}$ & Juncaceae & Hydrohalophyte & Therophyte \\
\hline 52 & Juncus maritimus & Juncaceae & Hydrohalophyte & Phanerophyte \\
\hline 53 & Koeleria pubescens & Poaceae & Psammophyte & Therophyte \\
\hline 54 & Koelpinia linearis & Asteraceae & Weedy & Therophyte \\
\hline 55 & Launea nudicaulis $^{* *}$ & Asteraceae & Xerohalophyte & Chamaephyte \\
\hline 56 & Launea resedifolia ${ }^{* *}$ & Asteraceae & Psammophyte & Chamaephyte \\
\hline 57 & Limoniastrum guyonianum $^{*}$ & Plumbaginaceae & Xerohalophyte & Chamaephyte \\
\hline 58 & Limonium echioides & Plumbaginaceae & Hydrohalophyte & Phanerophyte \\
\hline 59 & Limonium pruinosum & Plumbaginaceae & Hydrohalophyte & Therophyte \\
\hline 60 & Limonium sinuatum & Plumbaginaceae & Hydrohalophyte & Phanerophyte \\
\hline 61 & Limonium thouini & Plumbaginaceae & Hydrohalophyte & Therophyte \\
\hline 62 & Loefflingia hispanica & Caryophyllaceae & Psammophyte & Therophyte \\
\hline 63 & Lolium rigidum & Poaceae & Psammophyte & Phanerophyte \\
\hline 64 & Lotus corniculatus & Fabaceae & Psammophyte & Phanerophyte \\
\hline 65 & Lygeum spartum & Poaceae & Psammophyte & Phanerophyte \\
\hline 66 & Malva aegyptiaca & Malvaceae & Xerophyte & Therophyte \\
\hline 67 & Morettia canescens & Brassicaceae & Xerophyte & Therophyte \\
\hline 68 & Nitraria retusa & Zygophyllaceae & XeroHalophyte & Chamaephyte \\
\hline 69 & Noaea mucronata & Chenopodiaceae & XeroHalophyte & Chamaephyte \\
\hline 70 & Onopordon arenarium ${ }^{*}$ & Asteraceae & Psammophyte & Hemicryptophyte \\
\hline 71 & Papaver hybridum & Papaveraceae & Xerophyte & Therophyte \\
\hline 72 & Peganum harmala & Zygophyllaceae & Psammophyte & Chamaephyte \\
\hline 73 & Pholiurus uncurvus & Poaceae & Weedy & Therophyte \\
\hline 74 & Phalaris minor & Poaceae & Hydrohalophyte & Therophyte \\
\hline 75 & Phragmites communis & Poaceae & Hydrohalophyte & Phanerophyte \\
\hline 76 & Pistacia atlantica* & Anacardiaceae & Xerophyte & Phanerophyte \\
\hline
\end{tabular}




\section{Continued}

\begin{tabular}{|c|c|c|c|c|}
\hline 77 & Plantago albicans & Plantaginaceae & Psammophyte & Therophyte \\
\hline 78 & Poa bulbosa & Poaceae & Psammophyte & Chamaephyte \\
\hline 79 & Polygonum equisetiforme $e^{* *}$ & Polygonaceae & Xerohalophyte & Chamaephyte \\
\hline 80 & Pteranthus dichotomus & Paronychioideae & Xerogypsophyte & Therophyte \\
\hline 81 & Puccinella distans & Poaceae & Hydrohalophyte & Chamaephyte \\
\hline 82 & Reaumuria vermiculata ${ }^{* *}$ & Tamaricaceae & Hydrohalophyte & Chamaephyte \\
\hline 83 & Salicornia arabica ${ }^{* *}$ & Chenopodiaceae & Hydrohalophyte & Therophyte \\
\hline 84 & Salsola sieberi & Chenopodiaceae & Xerohalophyte & Chamaephyte \\
\hline 85 & Salsola tetragona & Chenopodiaceae & Xerohalophyte & Phanerophyte \\
\hline 86 & Salsola tetrandra & Chenopodiaceae & Xerohalophyte & Phanerophyte \\
\hline 87 & Salsola vermiculata & Chenopodiaceae & Xerohalophyte & Phanerophyte \\
\hline 88 & Schismus barbatus & Poaceae & Psammophyte & Therophyte \\
\hline 89 & Schoenus nigricans & Cyperaceae & Hydrohalophyte & Phanerophyte \\
\hline 90 & Scirpus holoschoenus & Cyperaceae & Hydrohalophyte & Hemicryptophyte \\
\hline 91 & Sisymbrium coronopifolium & Brassicaceae & Xerophyte & Therophyte \\
\hline 92 & Sisymbrium runciatum & Brassicaceae & Xerophyte & Therophyte \\
\hline 93 & Sisymbrium torulosum & Brassicaceae & Xerophyte & Therophyte \\
\hline 94 & Spergularia diandra & Paronychioideae & Xerohalophyte & Phanerophyte \\
\hline 95 & Spergularia marginata & Paronychioideae & Xerohalophyte & Phanerophyte \\
\hline 96 & Sphenopus divaricatus & Poaceae & Hydrohalophyle & Therophyte \\
\hline 97 & Stipa barbata & Poaceae & Psammophyte & Phanerophyte \\
\hline 98 & Stipa lagascae & Poaceae & Psammophyte & Phanerophyte \\
\hline 99 & Stipa parviflora & Poaceae & Psammophyte & Phanerophyte \\
\hline 100 & Stipa tenacissima & Poaceae & Psammophyte & Phanerophyte \\
\hline 101 & Suaeda fruticosa & Chenopodiaceae & Xerohalophyte & Phanerophyte \\
\hline 102 & Suaeda mollis & Chenopodiaceae & Xerohalophyte & Phanerophyte \\
\hline 103 & Tamarix africana & Tamaricaceae & Xerohalophyte & Phanerophyte \\
\hline 104 & Tamarix boveana & Tamaricaceae & Xerohalophyte & Phanerophyte \\
\hline 105 & Telephium imperati & Paronychioideae & Xerophyte & Hemicryptophyte \\
\hline 106 & Thapsia garganica & Apiaceae & Weedy & Hemicryptophte \\
\hline 107 & Thymelaea microphylla ${ }^{*}$ & Thymelaeaceae & Psammophyte & Chamaephyte \\
\hline 108 & Thymelaea virgata & Thymelaeaceae & Psammophyte & Chamaephyte \\
\hline 109 & Traganum nudatum & Chenopodiaceae & Xerohalophyte & Chamaephyte \\
\hline 110 & Trifolium fragiferum & Fabaceae & Psammophyte & Chamaephyte \\
\hline 111 & Vicia monantha & Fabaceae & Hydrohalophyte & Therophyte \\
\hline 112 & Zygophyllum cornutum ${ }^{*}$ & Zygophyllaceae & Xerohalophyte & Phanerophyte \\
\hline
\end{tabular}

${ }^{1}$ Plant type: This category is based on the habitats in which the taxon is distributed: Hydrohalophyte: Present in salt marshes; Xerophyte: Desert specie; Xerogypsophyte: Plant found on gypsum soils; Xerohalophyte: Salt desert specie; Psammophyte: Sand loving plant found on inland sand dunes; Weedy: Fugitive species; ${ }^{2}$ Life form: Only one life form is assigned per species, even though many species show a certain amount of plasticity in this regard: Phanerophyte: The buds were located at more than $50 \mathrm{~cm}$ of the soil $(>50 \mathrm{~cm}$ tall); Chamaephyte: The buds were located at less than $50 \mathrm{~cm}$ of the soil $(<50 \mathrm{~cm}$ tall); Therophytes: Germination occurs during the rainy season; Hemicryptophyte: The buds were located on the surface of the soil. 
families were Chenopodiaceae, Poaceae and Plumbaginaceae. Phanerophytes, Chamaephytes and Therophytes were the most frequent life forms. The highest number of halophyte species is present in the Chenopodiaceae family (19), followed by Poaceae (6), Plumbaginaceae (5), Fabaceae (3) and Tamaricaceae (3), while other families are represented by less than 16 halophytes (Table 1).

\section{Utilization and Economic Potential of Halophytes}

Halophytes have their greatest potential not so much in contributing to the world's food supply but primarily in their utilization of the growing areas of saline land for a range of different goals. The most important opportunities relate to reforestation or replanting and ecological recovery of saline areas that have fallen into disuse, coastal development and protection, and the production of cheap biomass for renewable energy, climate improvement and $\mathrm{CO}_{2}$ sequestration [10].

Halophytes seem to have much potential as a land cover cannot be denied, which is not only aesthetically pleasing but also checks land erosion and degradation. The more important opportunities relate to reforestation or replanting and ecological recovery of saline areas that have fallen into disuse, coastal development and protection, production of cheap biomass for renewable energy, environment conservation through carbon (C) sequestration, stabilization of coasts and beaches; and support to development of wild-life sanctuary and recreation areas [11].

\subsection{Food}

The only conventional crops species consumed by human beings as food, which tolerate salinity to a certain extent are beets (Beta vulgaris) and the date palm (Phoenix dactylifera), which can be irrigated with brackish water. The young leaves and shoots of Sesuvium portulacastrum, Atriplex halimus and A. hortensis, have also been used for vegetables, salads in various parts of the country [10].

\subsection{Forages and Fodders Production}

Halophytes are naturally adapted to vast areas of saltaffected range lands $[12,13]$ and they have been grazed or browsed by animals for a long time. Halophytic grasses, shrubs and trees are all potential sources of fodder. The greatest potential of halophytes probably rests with their utilization as forages and fodder.

The foliage of such species as Atriplex spp., Salsola spp. and Puccinellia spp., are used cattle feed. Many species of Salicornia spp., Chenopodium spp., Suaeda spp. and Kochia spp. are common fodder shrubs. Among grasses, Aeluropus litorallis, Poa bulbosa, Phragmites communis, Schismus barbatus, and Puccinellia distans are common species found in saline and alkaline areas and used as forages [14].

Many of the halophytic plant species and salt-tolerant species provide a valuable reserve feed for grazing animals particularly under drought conditions or fill regular gaps in feed supply caused by seasonal conditions [15]. The value of certain halophytic species has been recognized by their incorporation in pasture improvement programs in many salt-affected regions throughout the world [16]. There have been recent advances in selecting species with high biomass and protein levels and the ability to survive a wide range of environmental conditions including salinity [17]. Atriplex halimus has been field tested for domestic livestock and found to produce good fodder with biomass varied from 0.5 to $5 \mathrm{t} \cdot \mathrm{DW} \cdot \mathrm{ha}^{-1}$. This productivity is mainly related to the water availability and soil depth [17].

\subsection{Oil Seeds}

Seed of many halophytes contain appreciable amount of edible oils [18]. Seeds of various halophytes, such as Suaeda fruticosa, Arthrocnemum spp., Salicornia spp. and Halogeton spp. possess a sufficient quantity of high quality edible oil with unsaturation ranging from $70 \%$ $80 \%$ [19]. Thus, the exploration of economically important halophytes species may constitute an alternative source of edible oil.

\subsection{Fuel Wood and Coal}

Moderately to highly salt-tolerant trees, which can provide a range of wood and non wood products as well as other benefits are available. One of the most common uses of trees biomass is firewood [20].

In many developing countries people rely on wood for cooking and heating. Quite often fuel wood is obtained from salt tolerant trees and shrubs, which may include species of Prosopis spp., Tamarix spp., Salsola spp., Atriplex spp. and Suaeda spp. In addition species like Tamarix aphylla, and T. africana could provide good quality wood and also contribute to charcoal production [14].

In areas of moderate to high salinity, highly salt tolerant species, especially within the genus Acacia, which may have fuelwood value, may be used. The use of woody halophytes like mangrove as a source of charcoal for many years is a good example of using halophytes as fuel crop. Nevertheless, the anthropogenic impact, particularly the overcutting of these mangrove trees for wood, is increasing desertification in these areas [20].

\subsection{Medicinal Uses}

Many workers have reported the medicinal uses of halo- 
phytes while describing the economic importance of plants $[21,22]$. Halophytic plants are known to provide relief in the following diseases: Limonium spp.: Stop bleeding, promote urination and astringe; Glycyrrhiza spp.: Stop coughing, clean lungs; Apocynum venetum: Reduce blood pressure, strengthen heart and promote urination; Nitraria spp.: Normalize menstruation, promote blood circulation, help digestion and strengthen the spleen; Atriplex halimus: Antidiabetic effects; Plantago spp., Zygophyllum spp.: Flu and cough; Salsola tetrandra: Vermifuge; Plantago major: Diuretic [14].

\section{Restoration}

Globally, the ecology and importance of Chott lake ecosystems have been largely neglected. Chotts are probably the most poorly understood ecosystems, being neither good land, nor good water. Despite the status of Chott Zehrez as a Ramsar site, the main threat to its conservation is the private nature of surrounding land holdings in addition to the lack of knowledge and awareness by the local population of the importance of chott ecosystems. The development of any Chott conservation strategy in Algeria is also hindered by the lack of coordination between the ministries of environment and agriculture, as is common in many Mediterranean countries [1]. Furthermore, engaging local stakeholders in the development of conservation strategies often occur in the absence of any consideration of biodiversity issues. In Algeria for instance, there is no restriction on farmers to grow crops next to the Chott, neither is there a limit to livestock numbers. Therefore, continuing degradation by grazing and cultivation is resulting in the loss of habitats and associated species.

The local authorities should consider stricter control on damaging activities to these plant communities such as vegetation removal, cultivating or grazing. At the same time campaigns promoting the value of such ecosystems, the involvement of local communities and educational programs are necessary to raise local awareness and assist in the long term conservation of these ecosystems.

It is concluded that salt marshes are an integral component of the Chott lake ecosystem, serving as important areas of primary production for inland food chains. They are also an important habitat for the production of grazing animals. However, the diversity of the halophytes and other natural recourses in the salt lake in Algeria are, unfortunately, facing dangerous impacts due to the uncontrolled human interference. Many plant, animal, bird's species are either endangered or even exterminated. Such bad environmental situation and interference need urgent solutions through the conservation and sustainable use of the halophytic vegetation and its ecosystem in the salt marshes by applying several approaches such as:

1) Preserve the genetic resources of these species in the Algerian National Gene Bank,

2) Restoring the endangered species in its habitats,

3) Cultivating the economic halophytes species or crops of salinity resistant in habitat by using saline and brackish water of the lakes, and

4) Cultivating the multi-purposes halophytic species.

The feasibility of growing halophytes on salt Chott can be maximized with plant species that in addition to its primary product can also provide indirect and economical benefits.

The conservation and sustainable utilization of Chott lake ecosystem can be achieved through the development of appropriate legislation and laws to improve local community participation in decision-making, regulating access and utilization of rangelands. In addition, information and dissemination systems, and cooperation and coordination mechanisms should be established among national institutions.

\section{Conclusions}

Chott Zehrez lake, located in the north of Algeria, is a good example as a Ramsar site of international importance. The future conservation and management of the site therefore, require more detailed knowledge of their ecology and biodeversity. This review summarized the benefits and the constraints of halophytes and other salt-tolerant plants as economic potential resources in Chott Zehrez lake. It is concluded that:

- Halophytes and salt-tolerant species yield high edible biomass in saline lands where non-halophytic species cannot grow.

- The study has provided a clearer vision and recommendations to researchers and policy makers with regard to underutilized halophytic species and the importance of exploiting the potential of same in the future.

- In the view of the previous forecasts, it is necessary to emphasize that Chott lake ecosystem in fact demands urgent management action to conserve its threatened and unique ecosystem.

\section{Acknowledgements}

This research was financially supported by Algerian Ministry of Higher Education and Scientific Research (Projects PNR and CNEPRU No. F-02820100012).

\section{REFERENCES}

[1] M. Khaznadar, I. N. Vogiatzakis and G. H. Griffiths, "Land Degradation and Vegetation Distribution in Chott El Beida Wetland, Algeria," Journal of Arid Environments, 
Vol. 73, No. 3, 2009, pp. 369-377. doi:10.1016/j.jaridenv.2008.09.026

[2] M. Pouget, "Les Relations Sol-Végétation dans les Steppes Sud-Algéroises," Edition ORSTOM, Paris, 1980, 555 p.

[3] J. Aronson, "HALOPH; Salt Tolerant Plants for the World-A Computerized Global Data Base of Halophytes with Emphasis on Their Economic Uses," University of Arizona Press, Tucson, 1989.

[4] M. A. Khan and N. C. Duke, "Halophytes-A Resource for the Future," Wetlands Ecology and Management, Vol. 9, No. 6, 2001, pp. 455-456. doi:10.1023/A:1012211726748

[5] H. M. El Shaer, "Halophytes and Salt-Tolerant Plants as Potential Forage for Ruminants in the Near East Region," Small Ruminant Research, Vol. 91, No. 1, 2010, pp. 3-12. doi:10.1016/j.smallrumres.2010.01.010

[6] A. Boumezbeur and M. Benhadj, "Fiche Descriptive sur les Zones Humides RAMSAR, Chott Zahrez chergui (Algérie)," Direction Générale des Forêts, 2003, 10 p.

[7] M. Pouget, "Les Plages de Salure sur les Glacis Quaternaires a Croûte Calcaire," Bulletin Société Histoire Naturelle Afrique Nord, Vol. 64, No. 1-2, 1973, pp. 15-24.

[8] H. N. Le Houérou, "Biogeography of the Arid Steppeland North of the Sahara," Journal of Arid Environments, Vol. 48, No. 2, 2001, pp. 103-128. doi:10.1006/jare.2000.0679

[9] P. Quezel and S. Santa, "Nouvelle Flore de l'Algérie et des Régions Méridionales," Edition CNRS, Paris, 196, $1165 \mathrm{p}$.

[10] M. A. Khan and M. Qaiser, "Halophytes of Pakistan: Characteristics, Distribution and Potential Economic Usages," In: M. A. Khan, G. S. Kust, H. J. Barth and B. Böer, Eds., Sabkha Ecosystems, Vol. 2, Springer, Dordrecht, 2006, pp. 129-153.

[11] M. A. Khan and I. Aziz, "Salinity Tolerance of Some Mangroves from Pakistan," Wetland Ecology and Management, Vol. 9, 2001, pp. 228-332.

[12] H. N. Le Houérou, "The Role of Saltbushes (Atriplex spp.) in Arid Land Rehabilitation in the Mediterranean Basin: A Review," Agroforestry Systems, Vol. 18, No. 2, 1992, pp. 107-148. doi:10.1007/BF00115408

[13] B. Nedjimi and Y. Daoud, "Effects of Calcium Chloride on Growth, Membrane Permeability and Root Hydraulic Conductivity in Two Atriplex Species Grown at High (Sodium Chloride) Salinity," Journal of Plant Nutrition, Vol. 32, No. 11, 2009, pp. 1818-1830. doi:10.1080/01904160903242342

[14] M. A. Khan, R. Ansari, B. Gul and M. Qadir, "Crop Diversification through Halophyte Production on SaltProne Land Resources," CAB Reviews, Vol. 48, 2006, pp. 1-8.

[15] B. Nedjimi, "Salt Tolerance Strategies of Lygeum spartum L.: A New Fodder Crop for Algerian Saline Steppes," Flora, Vol. 204, No. 10, 2009, pp. 747-754. doi:10.1016/j.flora.2008.11.004

[16] B. Nedjimi, "Rangeland Improvement and Management Options in the Arid Steppes of Algeria," In: M. G. Denise, Ed., Steppe Ecosystems: Dynamics, Land Use and Conservation, Nova Science Publishers, Inc., New York, 2012, pp. 157-170.

[17] B. Nedjimi, "Seasonal Variation in Productivity, Water Relations and Ion Contents of Atriplex halimus subsp. schweinfurthii Grown in Chott Zehrez Wetland, Algeria," Journal of the Saudi Society of Agricultural Sciences, Vol. 11, 2012, pp. 43-49. doi:10.1016/j.jssas.2011.08.002

[18] A. Atia, A. Debez, Z. Barhoumi, C. Abdelly and A. Smaoui, "Localization and Composition of Seed Oils of Crithmum maritimum L. (Apiaceae)," African Journal of Biotechnology, Vol. 9, No. 39, 2010, pp. 6482-6485.

[19] D. J. Weber, R. Ansari, B. Gul and M. A. Khan, "Potential of Halophytes as Source of Edible Oil," Journal of Arid Environments, Vol. 68, No. 2, 2007, pp. 315-321. doi:10.1016/j.jaridenv.2006.05.010

[20] R. Choukr-Allah, "The Potential of Salt-Tolerant Plants for Utilisation of Saline Water," Options Méditerranéennes, Vol. 31, 1997, pp. 313-325.

[21] Z. Kefu, F. Hai and I.A. Ungar, "Survey of Halophyte Species in China," Plant Science, Vol. 163, No. 3, 2002, pp. 491-498. doi:10.1016/S0168-9452(02)00160-7

[22] B. Nedjimi, B. Guit, M. Toumi, B. Beladel, A. Akam and Y. Daoud, "Atriplex halimus subsp. schweinfurthii (Chenopodiaceae): Description, Usefulness and Therapeutic Virtue," Revue Fourrages, 2012, in Press. 